\title{
Bepridil and Amiodarone Simultaneously Target the Alzheimer's Disease $\beta$ - and $\gamma$-Secretase via Distinct Mechanisms
}

\author{
Stefan Mitterreiter, ${ }^{1}$ Richard M. Page, ${ }^{1}$ Frits Kamp, ${ }^{1}$ Jessika Hopson, ${ }^{2}$ Edith Winkler, ${ }^{1}$ Huy-Riem Ha, ${ }^{3}$ Runa Hamid, ${ }^{4}$ \\ Jochen Herms, ${ }^{4}$ Thomas U. Mayer, ${ }^{5}$ Deborah J. Nelson, ${ }^{2}$ Harald Steiner, ${ }^{1}$ Tobias Stahl, ${ }^{6}$ Ulrike Zeitschel, ${ }^{7}$ \\ Steffen Roßner, ${ }^{7}$ Christian Haass, ${ }^{1}$ and Stefan F. Lichtenthaler ${ }^{1}$ \\ ${ }^{1}$ German Center for Neurodegenerative Diseases Munich and Adolf Butenandt-Institute, Biochemistry, University of Munich, 80336 Munich, Germany, \\ ${ }^{2}$ Department of Neurobiology, Pharmacology and Physiology, University of Chicago, Chicago, Illinois 60637, ${ }^{3}$ Cardiovascular Therapy Research Laboratory, \\ Clinical Research Center, University Hospital Zurich, 8091 Zurich, Switzerland, ${ }^{4}$ Department of Neuropathology, University of Munich, 81377 Munich, \\ Germany, ${ }^{5}$ Department of Biology and Konstanz Research School Chemical Biology, University of Konstanz, 78452 Konstanz, Germany, and ${ }^{6}$ Veterinary \\ Anatomical Institute and 'Paul Flechsig Institute for Brain Research, University of Leipzig, 04109 Leipzig, Germany
}

The two proteases $\beta$-secretase and $\gamma$-secretase generate the amyloid $\beta$ peptide and are drug targets for Alzheimer's disease. Here we tested the possibility of targeting the cellular environment of $\beta$-secretase cleavage instead of the $\beta$-secretase enzyme itself. $\beta$-Secretase has an acidic pH optimum and cleaves the amyloid precursor protein in the acidic endosomes. We identified two drugs, bepridil and amiodarone, that are weak bases and are in clinical use as calcium antagonists. Independently of their calcium-blocking activity, both compounds mildly raised the membrane-proximal, endosomal $\mathrm{pH}$ and inhibited $\beta$-secretase cleavage at therapeutically achievable concentrations in cultured cells, in primary neurons, and in vivo in guinea pigs. This shows that an alkalinization of the cellular environment could be a novel therapeutic strategy to inhibit $\beta$-secretase. Surprisingly, bepridil and amiodarone also modulated $\gamma$-secretase cleavage independently of endosomal alkalinization. Thus, both compounds act as dual modulators that simultaneously target $\beta$ - and $\gamma$-secretase through distinct molecular mechanisms. In addition to Alzheimer's disease, compounds with dual properties may also be useful for drug development targeting other membrane proteins.

\section{Introduction}

Alzheimer's disease $(\mathrm{AD})$ is the most prevalent neurodegenerative disorder. The amyloid hypothesis ascribes the pathogenesis of the disease to a cascade of events, starting with the generation and accumulation of the amyloid $\beta$ peptide $(\mathrm{A} \beta)$, a proteolytic fragment of the amyloid precursor protein (APP) (Hardy and Selkoe, 2002). Formation of A $\beta$ requires APP to be proteolytically processed by the two proteases, $\beta$ - and $\gamma$-secretase. A third protease, $\alpha$-secretase, cleaves APP within the A $\beta$ domain and precludes $\mathrm{A} \beta$ generation. $\beta$-Secretase is the membrane-bound aspartyl protease BACE1 and cleaves APP at the $\mathrm{N}$ terminus of the A $\beta$ domain (Rossner et al., 2006; Cole and Vassar, 2008). This cleavage generates the soluble APPs $\beta$ and a C-terminal fragment (C99), which undergoes a second cleavage at the $\mathrm{C}$ terminus of the $\mathrm{A} \beta$ domain by $\gamma$-secretase. $\gamma$-Secretase belongs to the GxGDfamily of aspartyl proteases and cleaves APP within its hydropho-

Received March 9, 2010; accepted April 20, 2010.

This work was supported by the Alzheimer Forschung Initiative (to S.F.L.), the Deutsche Forschungsgemeinschaft (SFB596 project B12 to S.F.L., project B9 to C.H. and H.S., and project B6 to J.H.), the European Commission (NeuroNE to C.H. and S.F.L.), the Competence Network Degenerative Dementias (to S.F.L., H.S., and C.H.), and the Center for Integrated Protein Science Munich (to C.H.). We thank Katrin Moschke for excellent technical help.

Correspondence should be addressed to Stefan F. Lichtenthaler at the above address. E-mail: stefan. lichtenthaler@med.uni-muenchen.de.

DOI:10.1523/JNEUROSCI.1199-10.2010

Copyright $\odot 2010$ the authors $\quad 0270-6474 / 10 / 308974-10 \$ 15.00 / 0$ bic transmembrane domain. $\gamma$-Secretase is a heterotetrameric protein complex consisting of presenilin, nicastrin, PEN-2, and APH-1 (Steiner et al., 2008). $\gamma$-Secretase mainly cleaves after amino acid 40 of the $\mathrm{A} \beta$ sequence, resulting in the generation of the $A \beta 40$ peptide. To a lower extent, $\gamma$-secretase also generates $\mathrm{A} \beta 38$ and $\mathrm{A} \beta 42$. Although a minor product, $\mathrm{A} \beta 42$ is considered the key player in $\mathrm{AD}$ pathogenesis and is the main constituent of the amyloid plaques found in $\mathrm{AD}$ brains (Hardy and Selkoe, 2002).

$\beta$-Secretase is an obvious drug target for $\mathrm{AD}$, but most $\beta$-secretase inhibitors do not reach sufficiently high concentrations in the brain (Ghosh et al., 2008; Meredith et al., 2008). It is therefore essential to identify alternative strategies for reducing $\beta$-secretase cleavage. One possibility is the addition of a membrane anchor to a $\beta$-secretase inhibitor, which has been shown to increase its local membrane concentration, resulting in a more efficient $\beta$-secretase inhibition than the free inhibitor (Rajendran et al., 2008). Here we tested the possibility of targeting the cellular environment of $\beta$-secretase cleavage instead of the $\beta$-secretase enzyme itself. $\beta$-Secretase has an acidic $\mathrm{pH}$ optimum and mostly cleaves APP in the mildly acidic endosomes (Rossner et al., 2006), where it can be blocked by the weak base ammonium chloride (Haass et al., 1993; Schrader-Fischer and Paganetti, 1996). Interestingly, several drugs in clinical use contain weakly basic amino groups and thus have the potential to raise the endosomal $\mathrm{pH}$. 
We screened such compounds for an inhibition of $\beta$-secretase cleavage and identified the drugs bepridil and amiodarone as novel inhibitors of $\beta$-secretase cleavage. Both compounds are calcium channel blockers and calmodulin antagonists and are used for the treatment of heart disease. Here we found them to inhibit $\beta$-secretase cleavage and $\mathrm{A} \beta$ generation independently of their calcium channel- and calmodulin-blocking activities. The inhibition of $\beta$-secretase cleavage occurred at therapeutically achievable and nontoxic concentrations by raising the endosomal, membrane-proximal pH. Surprisingly, both compounds additionally modulated the cleavage specificity of $\gamma$-secretase in an inverse manner. Thus, bepridil and amiodarone define a new class of drugs - the dual modulators — which may be used for drug development targeting $\beta$ - and $\gamma$-secretase, either individually or simultaneously.

\section{Materials and Methods}

Antibodies and reagents. The following antibodies were used: 192wt and 192 swe (APPs $\beta$ wild-type and Swedish mutations, respectively, Elan Pharmaceuticals), W02 (APPs $\alpha$ ) and 22C11 [full-length APP (fl.APP), provided by K. Beyreuther, University of Heidelberg, Heidelberg, Germany], 6687 (fl.APP, Eurogentec), 6E10 (A $\beta 1-16$, Santa Cruz Biotechnology), 3552 (A $\beta$, Eurogentec), 2D8 (A $\beta 1-16$, provided by E. Kremmer, Helmholtz Institute, Munich, Germany), $\alpha$-A $\beta 38$ MSD-Tag (Meso Scale Discovery), $\alpha$-A $\beta 40$ BAP24-TAG and $\alpha$-A $\beta 42$ BAP24-TAG (provided by M. Brockhaus, Roche, Basel, Switzerland), $\alpha$-calmodulin (Millipore), and $\alpha$ - $\beta$-actin (Sigma). The reagents used were as follows: bepridil hydrochloride, amiodarone hydrochloride, chloroquine, nimodipine, and tamoxifen (Sigma); AMI-AcOH (provided by H.-R. Ha, University Hospital, Zurich, Switzerland); GL-189 (provided by K. Maskos and W. Bode, Max Plank Institute for Biochemistry, Martinsried, Germany); egg phosphatidylcholine (PC) (Avanti Polar Lipids); fluorescein phosphatidylethanolamine (FPE) (Invitrogen); and siRNA pools targeting Calmodulin genes calm 1 and calm 3 and nontargeting control pools (Dharmacon).

Cell culture, compound treatment, and immunoblots. Human embryonic kidney 293EBNA (HEK293) cells were cultured as described previously (Kuhn et al., 2007). Clonal H4 and U373 cells stably expressing APP751 from the vector pRC/CMV hAPPwt were cultured in DMEM supplemented with $10 \%$ fetal calf serum (FCS), $1 \%$ penicillin/streptomycin, and $200 \mu \mathrm{g} / \mathrm{ml} \mathrm{G} 418$ (G418-medium) or supplemented with 15\% FCS, respectively. Clonal HEK293 cells stably expressing APP695 from the vector pCEP4-APP695 (HEK293-APP) and polyclonal HEK293 cells stably expressing C99 from the vector pCEP4-SP-C99 were selected with $100 \mu \mathrm{g} / \mathrm{ml}$ hygromycin. HEK293-APPswe cells were cultured in G418medium as described previously (Haass et al., 1995). Cells were plated into poly-D-lysine-coated 24-well plates (BD Biosciences) or $6 \mathrm{~cm}$ dishes (for $\mathrm{A} \beta$ analysis by immunoblot). At confluence, cells were pretreated with compound or vehicle for $45 \mathrm{~min}$, then with fresh medium plus vehicle or compound for another $4-24 \mathrm{~h}$. Conditioned media and lysates were collected and immunoblots were performed as described previously (Schobel et al., 2008).

$A \beta$ detection. For $A \beta$ detection in the conditioned media, immunoprecipitation with antibody 3552 or $4 \mathrm{G} 8$ was performed before SDSPAGE. Proteins were transferred to nitrocellulose membranes. Total A $\beta$ was analyzed using a Tris-tricine gel (Schagger and von Jagow, 1987). A $\beta$ species were separated on $11 \%$ urea gels (Wiltfang et al., 1997). Signals were quantified using a Fluorchem 8900 device with AlphaEaseFC software. Sandwich immunoassay of individual $\mathrm{A} \beta$ species using the Meso Scale Discovery Sector Imager 2400 was described previously (Page et al., 2008).

In vitro BACE1 activity assay. For in vitro analysis of BACE1 activity, an established fluorometric assay was used (Capell et al., 2002). The assay was performed in a volume of $100 \mu \mathrm{l}$ containing $1 \mu \mathrm{l}$ of purified BACE1 ectodomain, $1 \mu \mathrm{M}$ substrate peptide (Cy3-SEVNLDAEFK(Cy5Q)- $\mathrm{NH}_{2}$, GE Healthcare), and the indicated concentrations of bepridil, the BACE1 inhibitor GL-189, or just the vehicle DMSO in $40 \mathrm{~mm}$ sodium acetate buffer $\mathrm{pH}$ 4.5. Fluorescence was measured continuously over a period of $2 \mathrm{~h}$ at room temperature (Fluoroskan Ascent, excitation $530 \mathrm{~nm}$, emission $590 \mathrm{~nm}$, Labsystems).

Lactate dehydrogenase release assay. HEK293-APP cells were plated into poly-D-lysine-coated 96-well plates (BD Biosciences) at a density of $2 \times 10^{4}$ cells/well in medium containing heat-inactivated fetal calf serum. On the next day, the medium was changed and the cells were incubated with different concentrations of bepridil or vehicle only for $24 \mathrm{~h}$ (8 wells/condition). Tamoxifen was used as a positive control. Forty-five minutes before the end of the incubation, the cells from three wells of each condition were lysed with Triton $\mathrm{X}-100\left(\mathrm{LDH}_{\max }\right)$. At the end of the incubation time, the amount of lactate dehydrogenase (LDH) in the conditioned media of the cells was analyzed using the CytoTox kit (Promega) according to the manufacturer's instructions. Toxicity was calculated as $\varnothing \mathrm{LDH}_{\text {samples }} / \varnothing \mathrm{LDH} \mathrm{H}_{\text {max }}$ for each condition (where $\varnothing$ is mean value).

Primary mouse neuronal cultures. Neuronal cultures were derived from fetal Tg2576 mouse brain at gestation day 16 as described previously (Hartlage-Rübsamen et al., 2003). Briefly, brains from fetuses were prepared and suspended in DMEM/Ham's F12 by trituration with glass pipettes. Neurons were separated by sequential passage of the cell suspension through nylon membranes (150 and $20 \mu \mathrm{m}$ ), centrifuged for 5 min at $800 \times g$, and resuspended in seeding medium (DMEM containing $5 \%$ horse serum and $1 \times P S N$ antibiotic mixture, where $P S N$ is penicillin, streptomycin, and neomycin). The cell number was determined and neurons were seeded at a density of 1.5 million cells per milliliter of culture medium in poly-L-lysine-coated 12-well plates. After $24 \mathrm{~h}$ of cultivation, the seeding medium was replaced by cultivation medium (25\% astrocyte conditioned medium in DMEM/Ham's F12, N2 supplement, and $1 \times$ PSN). On day 3 , in vitro neurons were used for pharmacological experiments. Cells were pretreated with compound or vehicle for $45 \mathrm{~min}$ then with fresh medium plus vehicle or compound for another $24 \mathrm{~h}$.

Organotypic brain slice cultures. Organotypic brain slice cultures were established from adult APP transgenic Tg2576 mice as described previously (Reimers et al., 2007). Briefly, mice were decapitated and brains were quickly prepared and mounted in $2 \%$ agarose in distilled water. Brain sections ( $350 \mu \mathrm{m}$ thick) were cut in the coronal plane using a vibratome (Leica). Brain sections were collected and maintained in culture plate inserts (Millicell CM, $30 \mathrm{~mm}$ diameter; Millipore) in DMEM/ Ham's F12 medium containing 25\% horse serum, 0.2\% D-glucose, $2 \mathrm{~mm}$ L-glutamine, and $0.3 \mathrm{~mm}$ HEPES. The medium was changed every other day and pharmacological treatments were initiated after a cultivation period of $4 \mathrm{~d}$. Slices were incubated for $16 \mathrm{~h}$ with serum-free medium, followed by pretreatment with vehicle or compound and then by incubation with fresh medium plus vehicle or compound for another $16 \mathrm{~h}$. The conditioned medium and brain slices were collected and stored in aliquots at $-20^{\circ} \mathrm{C}$ pending biochemical analyses.

Treatment of guinea pigs. Animal experiments were approved by Regierungspräsidium Leipzig (TVV 25/08). Female Duncin Hartley albino guinea pigs with a weight of 350-400 g were used (Charles River Laboratories). To account for variations in plasma $A \beta$ levels among individual animals, baseline $\mathrm{A} \beta 40$ concentration was analyzed in each guinea pig. Blood samples $(400 \mu \mathrm{l})$ were collected at 2:00 P.M. on the day before bepridil injection by puncture of the vena saphena lateralis. Heparin plasma was prepared by centrifugation at $2.500 \times g, 10 \mathrm{~min}$. The next day at 10:00 A.M., bepridil was injected intraperitoneally at $50 \mathrm{mg} / \mathrm{kg}$ body weight in a volume of $750 \mu \mathrm{l}$ of $10 \%$ DMSO, 10\% cyclodextran solution/ $100 \mathrm{~g}$ body weight. The positive control group received injections of DAPT $(60 \mathrm{mg} / \mathrm{kg}$ body weight). The negative control group received vehicle injections. Four hours after injection, guinea pigs were killed by $\mathrm{CO}_{2}$ inhalation, $1 \mathrm{ml}$ of blood was collected, and plasma was prepared as described above and stored at $-80^{\circ} \mathrm{C}$. In the time course experiment, blood was taken $4 \mathrm{~h}$ after injection and again at $28 \mathrm{~h}$ after injection. In this case, guinea pigs were killed at $28 \mathrm{~h}$ after injection. Plasma A $\beta 40$ concentrations before and after treatments were quantified by ELISA using the Biosource colorimetric assay kit according to the manufacturer's protocol. For each animal, the percentage amount of $A \beta 40$ present after treat- 
ment was calculated relative to baseline $A \beta 40$. Brain levels of endogenous $\mathrm{A} \beta$ were below the detection limit.

Measurement of the $\mathrm{pH}$ in the endolysosomal system of living cells. HEK293-APP cells were incubated for $30 \mathrm{~min}$ with tetramethylrhodamine (TMR)-fluorescein-tagged dextran $(5 \mathrm{mg} / \mathrm{ml})$ and the respective concentration of bepridil, amiodarone, or DMSO as a negative control. Cells were then washed three times with serum-free medium and reincubated for $1 \mathrm{~h}$ in fresh medium containing the compounds. Cells were imaged with a Leica SP2 AOBS inverted confocal microscope using a $63 \times$ oil objective lens (numerical aperture $=1.3$ ), exciting with a $488 \mathrm{~nm}$ and a $543 \mathrm{~nm}$ laser and emission bandwidths of $500-535 \mathrm{~nm}$ and $555-700 \mathrm{~nm}$, respectively. The red:green ratio (TMR:fluorescein) of selected regions of interest (ROI) was calculated and $\mathrm{pH}$ values of each region were interpolated from a calibration curve. The calibration curve was generated by loading the cells as above with TMR-fluorescein-tagged dextran but without compounds and incubating them for $15 \mathrm{~min}$ in a triplecomponent calibration buffer containing HEPES, CHES, and citric acid and the ionophores nigericin $(10 \mu \mathrm{M})$, valinomycin $(10 \mu \mathrm{M})$, bafilomycin $(0.1 \mu \mathrm{M})$, and monensin $(1 \mu \mathrm{M}) . \mathrm{pH}$ points between 4.5 and 7.0 with 0.5 increments were measured as described above (Di et al., 2006).

Measurement of the membrane-proximal pH using FPE. Twenty-five milligrams of egg PC were dissolved in low-salt buffer (20 mM HEPES$\mathrm{NaOH}, \mathrm{pH}$ 7.4) and hydrated for $1 \mathrm{~h}$ at room temperature (RT). Subsequently, small unilamellar vesicles (SUV) were prepared by sonication for 20 min at RT under a stream of argon gas as described previously (Kamp and Beyer, 2006). To incorporate the fluorescent probe FPE, a film of FPE was prepared by dissolving $36 \mu \mathrm{l}$ of a stock solution of FPE $(2.14 \mathrm{mg} / \mathrm{ml}$ in chloroform/methanol, $5: 1 \mathrm{v} / \mathrm{v})$ in $1 \mathrm{ml}$ of chloroform and evaporating the solvents under a gentle stream of nitrogen gas in a round bottom flask followed by $1 \mathrm{~h}$ vacuum. The SUV suspension $(1 \mathrm{ml}$, lipid concentration $25 \mathrm{~mm}$ ) was injected on top of the FPE film and gently shaken overnight at RT. Remaining aggregates of unbound FPE were removed by 5 min tabletop centrifugation. The supernatant contained SUV loaded with FPE. Changes in the membrane-proximal $\mathrm{pH}$ were measured by diluting the SUV suspension in a stirred cuvette with $2.5 \mathrm{ml}$ of buffer (final lipid concentration, $250 \mu \mathrm{M}$ ) and measuring the fluorescence of FPE (excitation at $490 \mathrm{~nm}$, emission at $520 \mathrm{~nm}$ ). Aliquots of the tested compounds were added with a Hamilton syringe through the pinhole of the fluorimeter (Jasco FP 6300).

Fluorescence-based measurement of intracellular calcium levels. Cytosolic $\mathrm{Ca}^{2+}$ was measured in HEK293-APP cells using the fura 2/AM dye (Invitrogen) as described previously (Hamid et al., 2007). Cells were viewed with an upright microscope (BX50WI, Olympus) using a $20 \times$ water-immersion objective. Excitation of the cells was performed at 340 $\mathrm{nm}$ for the $\mathrm{Ca}^{2+}$-bound form and $380 \mathrm{~nm}$ for the unbound form of fura 2 and the ratio of the emissions was obtained using a digital imaging system (Till Photonics). $\mathrm{Ca}^{2+}$ concentrations were calculated from fluorescence-intensity ratios using the following equation (Grynkiewicz et al., 1985):

$$
\left[\mathrm{Ca}^{2+}\right]=K_{\mathrm{d}} \times \beta\left[\left(R-R_{\min }\right) /\left(R_{\max }-R\right)\right],
$$

where $K_{\mathrm{d}}$ is the dissociation constant of fura 2 for $\mathrm{Ca}^{2+}\left(K_{\mathrm{d}}=224 \mathrm{nM}\right), \beta$ is the fluorescence ratio of the $380 \mathrm{~nm}$ signal in the absence of $\mathrm{Ca}^{2+}$ to that in the presence of saturating $\mathrm{Ca}^{2+}, R$ is the fluorescence ratio obtained using a calcium calibration buffer kit (Invitrogen). All experiments were performed at room temperature and drugs were applied by bath perfusion.

Knockdown of calmodulin using siRNAs followed by compound treatment. HEK293-APP cells were plated at a density of $1 \times 10^{5}$ cells/well into poly-D-lysine-coated 24-well plates. After $4 \mathrm{~h}$, cells were transfected with a mixture of siRNA pools against calm 1 and calm 3 or control pools using Lipofectamine2000 (Invitrogen) according to the manufacturer's instructions. Two days after transfection, cells were treated with bepridil or vehicle as described above.

In vitro $\gamma$-secretase assay. Purification of $\gamma$-secretase and in vitro assays were performed as described previously (Winkler et al., 2009). The Q-Sepharose eluate fraction of purified $\gamma$-secretase was used as enzyme source.

\section{Results}

\section{Alkalizing drugs inhibit $\boldsymbol{\beta}$-secretase cleavage of APP at therapeutically relevant concentrations}

First, we verified that the known alkalizing drugs ammonium chloride and chloroquine block $\beta$-secretase cleavage in HEK293APP cells (supplemental Fig. 1, available at www.jneurosci.org as supplemental material). Next, we tested bepridil and amiodarone. Bepridil is in clinical use in France and Japan for the treatment of angina pectoris. Amiodarone is widely used for the treatment of arrhythmias. Both compounds are cationic amphiphilic drugs and have a hydrophobic core with two aromatic rings (Fig. 1A), which allows them to partition into the membrane. The hydrophobic core is linked through a short aliphatic spacer to a protonatable tertiary amino group (Fig. $1 A$, arrows), which acts as a weak base.

To investigate the effect of bepridil on $\beta$-secretase cleavage in detail, HEK293-APP cells were treated for $4 \mathrm{~h}$ with bepridil or with DMSO as a control. Secreted APP and $A \beta$ were detected in the conditioned medium. Bepridil inhibited the generation of $\mathrm{APPs} \beta$ and $\mathrm{A} \beta$ in a dose-dependent manner (Fig. $1 B-D$ ). In contrast to the inhibition of $\beta$-secretase cleavage, APPs $\alpha$ was largely unaffected by bepridil treatment. The amount of fulllength APP in the cell lysate (immature and mature form) was not altered. Similar results for the inhibition of APPs $\beta$ generation were obtained for neuroglioma $\mathrm{H} 4$ and astroglioma U373 cells stably expressing APP and for the endogenous APPs $\beta$ derived from HEK293 cells (supplemental Fig. 2, available at www. jneurosci.org as supplemental material). The $\mathrm{IC}_{50}$ for the inhibition of $\mathrm{APPs} \beta$ and $\mathrm{A} \beta$ generation was $\sim 6 \mu \mathrm{M}$ (Fig. $1 C, D$ ), which is in the concentration range of bepridil found in the plasma of patients $(3-10 \mu \mathrm{M})$ (Hollingshead et al., 1992). No cellular toxicity was observed below $50 \mu \mathrm{M}$, as determined in a lactate dehydrogenase release assay (supplemental Fig. 3, available at www. jneurosci.org as supplemental material). This is in line with the fact that bepridil is used for chronic treatment. The inhibition of $\beta$-secretase cleavage occurred in an indirect manner, because bepridil was not able to block the activity of the $\beta$-secretase BACE1 in an established in vitro assay (Fig. $1 E$ ), which uses soluble BACE1 and measures the cleavage of a fluorophor-tagged APPderived substrate peptide (Capell et al., 2002). In contrast, a known active site inhibitor of BACE1, GL-189 (Capell et al., 2002), fully blocked BACE1 activity in this assay (Fig. $1 E$ ). The indirect inhibition of $\beta$-secretase cleavage is in agreement with the proposed alkalinization of the endosomal $\mathrm{pH}$ being the mechanism of $\beta$-secretase inhibition. Amiodarone inhibited $\beta$-secretase cleavage in a similar manner as bepridil with an $\mathrm{IC}_{50}$ of $\sim 30 \mu \mathrm{M}$ (Fig. $1 F, G$ ). The therapeutically achievable plasma concentration of amiodarone is 1.5-6 $\mu \mathrm{M}$ (Freedman and Somberg, 1991). At this concentration, $\beta$-secretase cleavage was inhibited by $10-20 \%$ (Fig. $1 F, G$ ). From the data above, we conclude that, at therapeutically achievable concentrations, amiodarone and bepridil are novel inhibitors of $\beta$-secretase cleavage of APP and of $A \beta$ generation.

\section{Bepridil reduces $A \boldsymbol{\beta}$ levels in primary neurons, in organotypic brain slice cultures, and in vivo in the plasma of guinea pigs} Next, we tested whether the inhibition of $\beta$-secretase cleavage and $\mathrm{A} \beta$ generation by bepridil was also observed in primary neurons, in organotypic brain slice cultures, and in animals. Primary neurons were prepared from Tg2576 mice, which are an established mouse model of AD pathology and overexpress the Swedish mutant form of APP (Hsiao et al., 1996). Bepridil reduced APPs $\beta$ 
A<smiles>CC(C)COCC(CN(Cc1ccccc1)c1ccccc1)N1CCCC1</smiles><smiles>CCCCc1oc2ccccc2c1C(=O)c1cc(I)c(OCCN(CC)CC)c(I)c1</smiles>

amiodarone

\section{C}

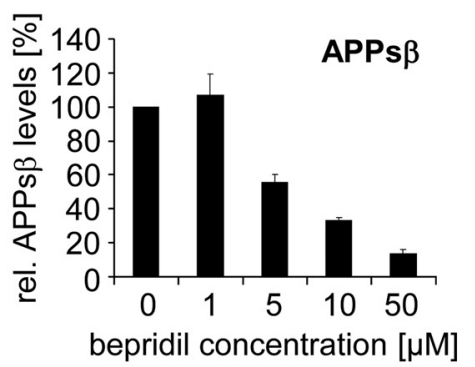

E

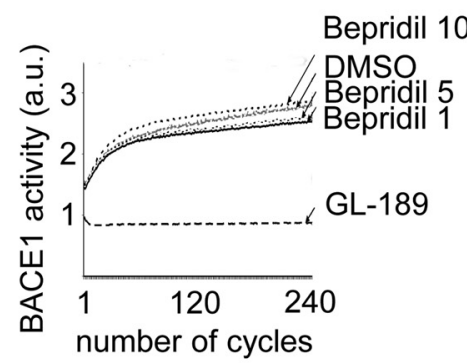

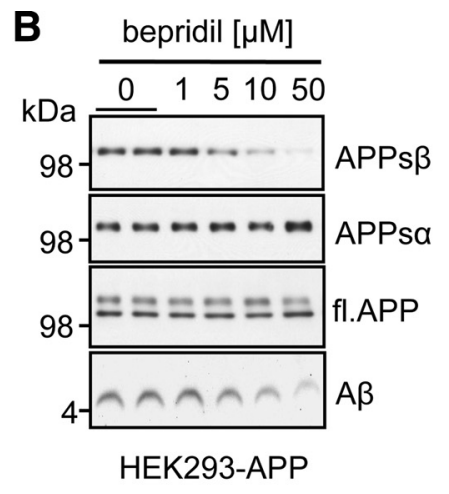

D

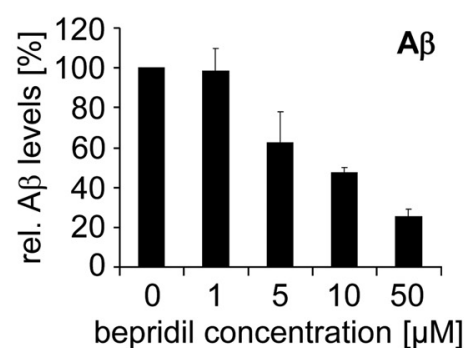

$\mathbf{F}$

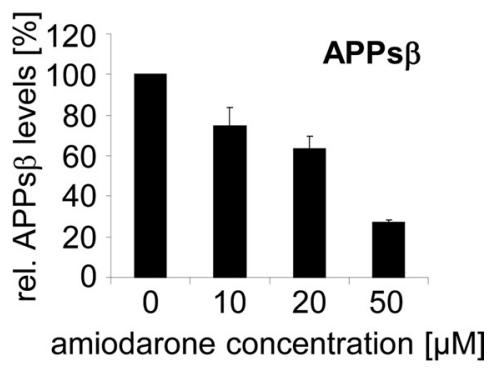

G

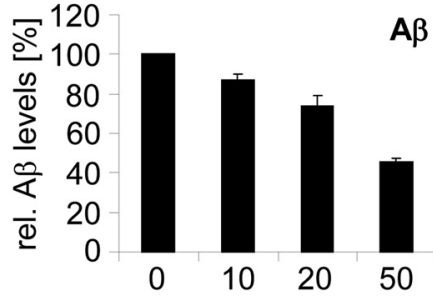

amiodarone concentration $[\mu \mathrm{M}]$

Figure 1. Bepridil and amiodarone are novel inhibitors of $\beta$-secretase cleavage. $A$, Structure of bepridil and amiodarone. The protonatable amino group is marked (arrow). The second amino group in bepridil cannot be protonated due to a low pKa. $B$, HEK293-APP cells were treated with bepridil for $4 \mathrm{~h}$ and the different APP species were analyzed by immunoblot. APPs $\beta$ and APPs $\alpha$ were detected in the conditioned medium using antibodies $192 \mathrm{wt}$ and W02, respectively. A $\beta$ was detected using the antibody 6E10. fl.APP was detected in the cell lysate using the antibody 22C11. Bepridil caused a selective decrease in APPs $\beta$ and $A \beta$. $($ and $\boldsymbol{D}$, Results from $\boldsymbol{B}$ were quantified for $A P P s \beta$ and $A \beta$. Shown are the mean and SD of four $(\boldsymbol{C})$ and two $(\boldsymbol{D})$ independent experiments. $\boldsymbol{E}$, The effect of bepridil was analyzed in an in vitro BACE1 activity assay using a fluorogenic APP-derived peptide substrate. Bepridil did not inhibit BACE1 activity, whereas the BACE1 inhibitor GL-189 completely blocked the activity of the enzyme. Concentrations of bepridil are given in $\mu$ M. a.u., Arbitrary units; rel., relative. $\boldsymbol{F}$ and $\mathbf{G}$, Treatment of HEK293-APP cells with amiodarone as in $\boldsymbol{B}$. Shown are mean and SD of APPs $\beta$ and $A \beta$ from three independent experiments.

and $\mathrm{A} \beta$ generation in the primary neurons in a dose-dependent manner and with similar $\mathrm{IC}_{50}$ values as in the cell lines (Fig. $2 A, B)$. Then the effect of bepridil on $\mathrm{A} \beta$ generation was tested in organotypic brain slice cultures of Tg2576 mice. Also in this setting, bepridil reduced $\mathrm{A} \beta$ generation in a dose-dependent man- ner (Fig. 2C), demonstrating that the inhibitory effect is not only seen in cultured cells ex vivo, but also directly in the brain tissue. Bepridil lowered $\mathrm{A} \beta$ production to a similar extent as the well characterized $\gamma$-secretase inhibitor DAPT (Fig. 2C) (Dovey et al., 2001). Compared with cell lines and primary neurons, higher concentrations of bepridil and DAPT were required for inhibition in brain slices. Presumably, both compounds do not fully penetrate the $350-\mu \mathrm{m}$-thick slice at lower concentrations or are partly bound by lipids and proteins in the slice. At these concentrations, no toxicity was observed. Full-length APP and actin levels were not significantly changed in the lysates prepared from the slices (data not shown).

To test whether bepridil also reduces $\mathrm{A} \beta$ levels in vivo, guinea pigs were used. Compared with mice, guinea pigs have a larger body weight and blood volume, which allows one to draw blood before and after bepridil treatment and to determine $\mathrm{A} \beta$ changes within one animal. Guinea pigs were treated with bepridil (50 $\mathrm{mg} / \mathrm{kg}$, i.p.), which corresponds to a starting concentration of $\sim 20 \mu \mathrm{M}$ in plasma (Shiotani et al., 2005), or with the $\gamma$-secretase inhibitor DAPT $(60 \mathrm{mg} / \mathrm{kg}$ ) as a positive control (Lanz et al., 2003). Endogenous $A \beta 40$ in the plasma was measured by ELISA. Plasma levels of endogenous $\mathrm{A} \beta 38$ and $\mathrm{A} \beta 42$ were below the detection limit. Initially, a time course pilot experiment was performed using two animals in the bepridil group and three animals in the control group. Plasma A $\beta 40$ levels were reduced $4 \mathrm{~h}$ after bepridil injection and returned to control levels at $28 \mathrm{~h}$ after treatment (data not shown).

Next, we examined a larger number of guinea pigs $(n=8)$ at the $4 \mathrm{~h}$ time point. Twenty hours before treatment as well as $4 \mathrm{~h}$ after compound treatment, blood was drawn from all animals and analyzed for $\mathrm{A} \beta 40$. Bepridil reduced plasma levels of A $\beta 40$ by $\sim 50 \%$ compared with controltreated animals (Fig. 2D). A similar reduction of $A \beta 40$ was observed for the positive control DAPT (Fig. 2D).

Together, the above experiments demonstrate that bepridil is able to block $\beta$-secretase cleavage and lower $\mathrm{A} \beta$ generation in primary neurons, in organotypic brain slice cultures, and in vivo in guinea pigs.

Bepridil and amiodarone raise the $\mathrm{pH}$ in endocytic compartments

Next, we tested whether bepridil and amiodarone are able to raise the $\mathrm{pH}$ in the acidic compartments of the endocytic pathway in 
living cells, where $\beta$-secretase cleavage takes place (Rossner et al., 2006). To this aim, HEK293-APP cells were loaded with dextran carrying two different fluorescent tags. The $\mathrm{pH}$-sensitive fluorescein acts as a $\mathrm{pH}$ sensor, whereas tetramethylrhodamine serves as a loading control and allows for ratiometric measure of $\mathrm{pH}$. The TMRdextran-fluorescein molecule is taken up into cells by endocytosis and labels endosomes and lysosomes. Treatment with bepridil led to a concentration-dependent increase of the $\mathrm{pH}$ from 5.1 to 5.5 in the endolysosomal pathway (Table 1). This $\mathrm{pH}$ increase is in agreement with the observed inhibition of BACE1, because BACE1 has a narrow $\mathrm{pH}$ optimum at $\mathrm{pH}$ 4.5-4.8, and its activity can be inhibited by small changes in the $\mathrm{pH}$ (Shimizu et al., 2008). Amiodarone had an effect on the $\mathrm{pH}$ comparable to bepridil (supplemental Table 1, available at www.jneurosci.org as supplemental material). Together, these results demonstrate that bepridil and amiodarone mildly alkalinize endosomal and lysosomal compartments of living cells.

\section{Bepridil and amiodarone raise the membrane-proximal $\mathrm{pH}$}

Bepridil and amiodarone are cationic amphiphilic drugs, which penetrate into biological membranes. As a consequence, the positively charged, basic amino group localizes closely to the membrane surface where it can repel protons, leading to a local $\mathrm{pH}$ increase. This suggests that bepridil and amiodarone may increase the $\mathrm{pH}$ primarily in the membrane-proximal zone, where the $\beta$-secretase cleavage site in the APP sequence is located, without affecting the bulk $\mathrm{pH}$. Direct experimental proof in living cells is difficult, because the fluorescently labeled dextran used above does not allow one to distinguish between $\mathrm{pH}$ changes occurring in the bulk of the endolysosomal lumen versus those that are restricted to the membrane-proximal area. To test for possible $\mathrm{pH}$ changes in the membrane-proximal area, an in vitro assay was used. A lipid-linked $\mathrm{pH}$ sensor was incorporated into lipid vesicles prepared from egg phosphatidylcholine (for a schematic drawing, see supplemental Fig. 4, available at www.jneurosci.org as supplemental material). The sensor consists of the $\mathrm{pH}$-sensitive fluorophor fluorescein coupled to phosphatidylethanolamine. The unprotonated form of fluorescein, which is present under basic conditions, shows a higher fluorescence than the protonated form, which is predominant under acidic conditions. This system has been successfully used in the past for the measurement of changes in surface potential and $\mathrm{pH}$ in the membrane-proximal zone (Teissie et al., 1985; Simard et al., 2008). Bepridil and amiodarone were used at concentrations of 10 and $20 \mu \mathrm{M}$, which corresponds to the concentrations at which $\beta$-secretase inhibition was observed in the cellular assay. Bepridil and amiodarone increased the fluorescence of fluorescein in a dose-dependent manner compared with control (Fig. 3A). The increase in fluorescence was equivalent to an increase of the membrane-proximal $\mathrm{pH}$ by 0.4 or $0.6 \mathrm{U}$ for $20 \mu \mathrm{M}$ bepridil or
B
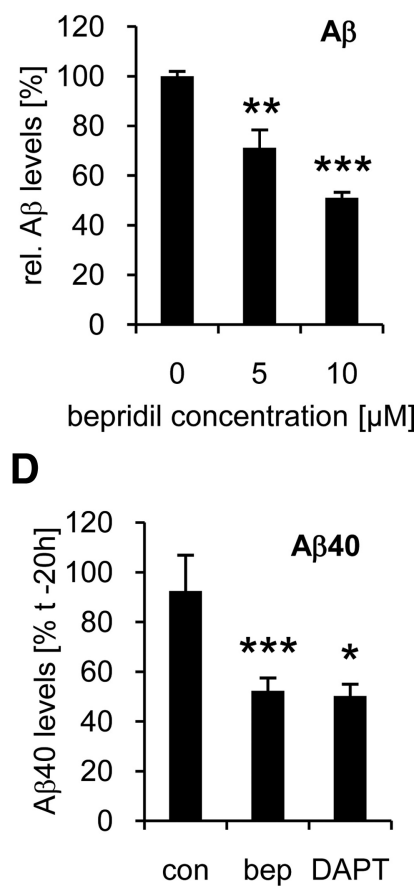

con bep DAPT

con B20 B50 B100 DAPT

Figure 2. Bepridil inhibits $A \beta$ generation in primary neurons, organotypic brain slice cultures, and in guinea pigs. $A$ and $\boldsymbol{B}$, Pry neurons from Tg2576 mice were treated for $24 \mathrm{~h}$ with bepridil. Full-length APP and APP cleavage products were detected primary neurons. Shown are the mean and SD of $A P P S \beta(A)$ and $A \beta(B)$ from six experiments. $C$, Organotypic brain slice cultures significant decrease of A $\beta 40$ compared with animals injected with control medium only. rel., Relative. ${ }^{*} p<0.05{ }^{*}{ }^{* *} p<0.01$; ${ }^{* * *} p<0.001$ compared with control, determined with unpaired two-tailed $t$ test.

Table 1. Bepridil raises $\mathrm{pH}$ in endocytic pathway

\begin{tabular}{ll}
\hline Concentration $(\mu \mathrm{M})$ & $\mathrm{pH}$ \\
\hline 0 & $5.1 \pm 0.02$ \\
5 & $5.2 \pm 0.05$ \\
10 & $5.3 \pm 0.03$ \\
15 & $5.3 \pm 0.04$ \\
20 & $5.4 \pm 0.05$ \\
30 & $5.5 \pm 0.05$
\end{tabular}

Mean \pm SEM, $n>50$.

amiodarone, respectively, as determined by a $\mathrm{pH}$ titration curve (supplemental Fig. 5, available at www.jneurosci.org as supplemental material). This increase is similar to the change observed in the cellular system above (Table 1). Importantly, the compounds did not affect the $\mathrm{pH}$ of the bulk solution, as measured with a $\mathrm{pH}$ electrode. As a control for the assay, the lipid 1-tetradecylamine was used, which caused an increase in the membrane-proximal $\mathrm{pH}$, as expected for this amino group containing basic lipid (Fig. $3 B$ ). As an additional control, a derivative of amiodarone (AMI-AcOH) was used, which contains a carboxylic acid group instead of the amino group of amiodarone (Fig. 3C). AMI-AcOH lowered the membrane-proximal pH (Fig. 3B). As expected from these data, AMI-AcOH did not block $\beta$-secretase cleavage (Fig. $3 D$ ), which further supports that the 
A

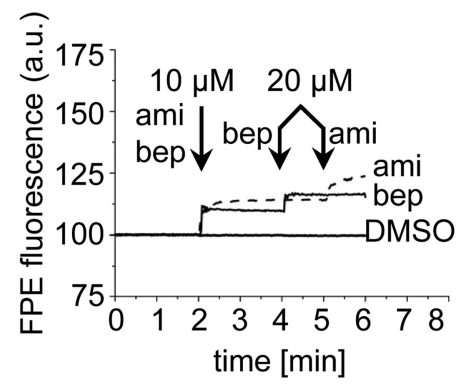

C<smiles>CCCCc1oc2ccccc2c1C(=O)c1cc(I)c(OCC(=O)O)c(I)c1</smiles>

$\mathrm{AMI}-\mathrm{AcOH}$
B

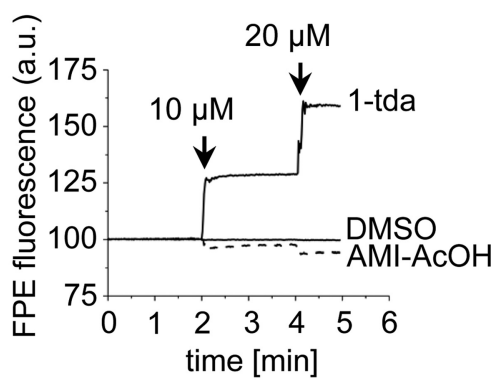

D

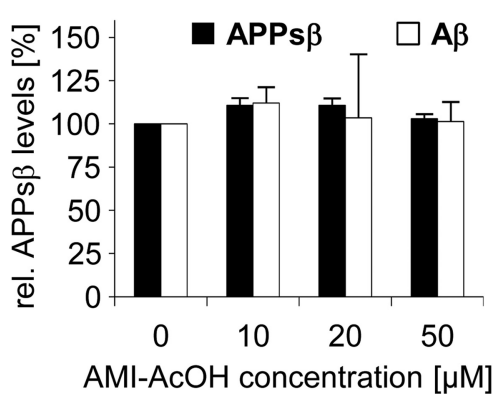

Figure 3. Bepridil and amiodarone raise the membrane-proximal $\mathrm{pH}$. $\boldsymbol{A}$ and $\boldsymbol{B}$, Measurements of the fluorescence of FPE incorporated into membrane-like lipid vesicles. Bepridil (bep) or amiodarone (ami) $(\boldsymbol{A})$ or the controls 1-tetradecylamine (1-tda) or $\mathrm{AMI}-\mathrm{ACOH}(\boldsymbol{B})$ were added at the indicated time points. Concentrations of 10 and $20 \mu \mathrm{m}$ were used. Bepridil, amiodarone, and the control 1-tda caused an increase in the fluorescence intensity of FPE, showing that they alkalinize the $\mathrm{pH}$ in the membraneproximal zone. In contrast, $\mathrm{AMI}-\mathrm{ACOH}$ caused a decrease in the membrane-proximal pH. rel., Relative; a.u., arbitrary unit. C, Structure of AMI-AcOH. D, HEK293-APP cells were treated for $4 \mathrm{~h}$ with AMI-AcOH. AMI-AcOH did not lead to a decrease of APPs $\beta$ and $A \beta$, demonstrating that the basic amino group is essential for the inhibition of $\beta$-secretase cleavage. Shown are the mean and SD of two independent experiments.

amino group and the alkalizing activity are required for blocking $\beta$-secretase cleavage.

\section{Inhibition of $\boldsymbol{\beta}$-secretase cleavage is independent of calcium changes and calmodulin}

Bepridil and amiodarone are known calcium channel blockers and calmodulin (CaM) antagonists, but their mechanism of action is not fully understood. If the inhibitory effect on $\beta$-secretase cleavage is indeed due to the compounds' alkalizing activity, it should be independent of calcium channel inhibition and CaM. Indeed, the specific calcium channel blocker nimodipine, which is unrelated to bepridil and amiodarone, did not affect APP processing at concentrations where calcium channels in HEK293 cells are potently blocked (supplemental Fig. 6A, available at www.jneurosci.org as supplemental material) (Berjukow et al., 1996), which is in agreement with a previous publication (Facchinetti et al., 2006). Furthermore, bepridil did not alter intracellular calcium levels as determined in HEK293-APP cells loaded with the calcium-indicator dye fura 2 (supplemental Fig. 6B, available at www.jneurosci.org as supplemental material). Moreover, bepridil still potently inhibited APPs $\beta$ generation in CaM knockdown cells (supplemental Fig. 6C, available at www.jneurosci.org as supplemental material). Together, these experiments exclude that changes in cellular calcium or $\mathrm{CaM}$ are responsible for the inhibition of $\beta$-secretase cleavage by bepridil and amiodarone.

\section{Bepridil and amiodarone modulate cleavage specificity of $\boldsymbol{\gamma}$-secretase}

Generation of $\mathrm{A} \beta$ requires the action of both $\beta$ - and $\gamma$-secretase. Because $\gamma$-secretase has multiple cleavage sites, $A \beta$ species of dif- ferent length are generated-mainly $\mathrm{A} \beta 40$ and, to a lower extent, $\mathrm{A} \beta 38$ and $\mathrm{A} \beta 42$. Some small molecule drugs, called $\gamma$-secretase modulators (GSM), shift the $\gamma$-secretase cleavage site. Straight GSMs (sGSMs) lower $\mathrm{A} \beta 42$ and raise $\mathrm{A} \beta 38$ (Weggen et al., 2001), whereas inverse GSMs (iGSM) do the opposite (Kukar et al., 2005). To investigate whether bepridil-in addition to its inhibitory effect on $\beta$-secretase cleavage-modulates $\gamma$-secretase cleavage, C99-expressing HEK293 cells were used. C99 is the C-terminal APP fragment arising through $\beta$-secretase cleavage and allows monitoring $\gamma$-cleavage independently of $\beta$-cleavage. Total levels of $A \beta$ as well as levels of $A \beta 38, A \beta 40$, and $A \beta 42$ were measured. Surprisingly, bepridil increased A $\beta 42$ by approximately twofold and reduced $\mathrm{A} \beta 38$ to $\sim 50 \%$, whereas levels of $\mathrm{A} \beta 40$ and total $\mathrm{A} \beta$ remained unchanged (Fig. $4 A, B)$. A similar result was obtained in an in vitro $\gamma$-secretase assay, where purified $\gamma$-secretase, reconstituted into lipid vesicles together with C99 as a substrate, was incubated with bepridil (Fig. 4C). Generation of the APP intracellular domain (AICD), which is the second $\gamma$-secretase cleavage product, was not affected in the in vitro assay (supplemental Fig. 7, available at www.jneurosci.org as supplemental material), revealing that bepridil does not inhibit $\gamma$-secretase activity, but instead modulates the cleavage site of $\gamma$-secretase and the $\mathrm{A} \beta$ species being generated. Together, these experiments demonstrate that bepridil acts as an iGSM.

Next we measured whether the iGSM effect was also observed in cells expressing full-length APP instead of C99. To measure the $\mathrm{A} \beta$ species in a sandwich immunoassay, HEK293-APPswe cells were used, which produce more A $\beta$ than HEK293-APP wild-type cells. In contrast to C99-expressing cells, bepridil reduced total $\mathrm{A} \beta$ levels (Fig. $4 D$ ) due to an inhibition of $\beta$-secretase cleavage, which is in agreement with the findings in Figure $1 D$. Generation of the main $A \beta$ species $A \beta 40$ was inhibited to a similar extent as total $A \beta$. However, $A \beta 38$ was even more strongly inhibited, whereas $\mathrm{A} \beta 42$ was only mildly affected by bepridil (Fig. $4 D$ ). Thus, $A \beta 42$ levels were highest, followed by $A \beta 40$ and $A \beta 38$, which is comparable to the effects observed in the C99-expressing cells (Fig. $4 A, B$ ). Similar results were observed for bepridil in primary neurons obtained from Tg2576 mice (Fig. $4 E$ ). An even stronger iGSM effect than for bepridil was observed for amiodarone. This compound strongly increased $A \beta 42$, mildly reduced $\mathrm{A} \beta 40$, and more strongly lowered A $\beta 38$ in HEK293-APPswe cells (Fig. $4 F$ ). Compared with bepridil, the milder effect of amiodarone on the main $A \beta$ species $A \beta 40$ is in agreement with the higher $\mathrm{IC}_{50}$ value for $\beta$-secretase inhibition. Together, the results demonstrate that bepridil and amiodarone act as dual modulators. They inhibit $\beta$-secretase cleavage of APP and simultaneously modulate $\gamma$-secretase cleavage.

To determine whether the GSM effect-similar to the inhibition of $\beta$-secretase cleavage-requires the amino group, we tested the effect of the amiodarone derivative $\mathrm{AMI}-\mathrm{AcOH}$ on the generation of the individual $\mathrm{A} \beta$ species. $\mathrm{AMI}-\mathrm{AcOH}$ lacks an amino 
group and is not able to raise the membrane-proximal $\mathrm{pH}$ (Fig. $3 B, C$ ). AMI-AcOH still modulated the $\gamma$-secretase cleavage (Fig. 4G). This reveals that the amino group is not required for GSM activity, which is in agreement with the observation that the GSM activity of bepridil was also observed in the $\gamma$-secretase in vitro assay (Fig. 4C). Surprisingly, AMI$\mathrm{AcOH}$ lowered $\mathrm{A} \beta 42$ and raised $\mathrm{A} \beta 38$ (Fig. 4G) and thus had the opposite GSM effect (sGSM) compared with amiodarone (iGSM). When comparing the structure of other known sGSMs and iGSMs (Weggen et al., 2001; Kukar et al., 2005), we observed that both classes have a hydrophobic, aromatic core, but that sGSMs additionally have a free carboxylic acid group as it is found in AMI-AcOH (Fig. $3 C)$. This suggests that the carboxylic acid group determines whether a GSM acts as an iGSM or a sGSM and thus defines a structural feature required for sGSM activity.

\section{Discussion}

The proteases $\beta$ - and $\gamma$-secretase directly generate the $\mathrm{A} \beta$ peptide and are considered main drug targets for Alzheimer's disease. However, clinically suitable inhibitors for both proteases have been difficult to find. Our study identifies and mechanistically characterizes the two clinically used compounds bepridil and amiodarone, which we found to act as dual modulators on APP processing. They inhibit $\beta$-secretase cleavage and simultaneously modulate $\gamma$-secretase cleavage. The mechanistic analysis shows that both effects occur through distinct molecular mechanisms and require different chemical groups of the compounds. This provides a blueprint for the development of new drugs indirectly inhibiting $\beta$-secretase, modulating $\gamma$-secretase, or targeting both enzymes simultaneously.

$\beta$-Secretase inhibitors need to reach the endosome where $\beta$-secretase cleavage of APP mostly takes place. For example, a recent study showed that membraneanchoring of a BACE1 inhibitor allowed its endocytosis, increased its local membrane concentration in the endosome, and inhibited BACE1 activity more efficiently than the free inhibitor (Rajendran et al., 2008). Here, we report that inhibition of $\beta$-secretase cleavage can also be achieved using the alkalizing properties of bepridil and amiodarone. For the first time we show that both compounds mildly raise the $\mathrm{pH}$ in acidic compartments of living cells and increase the membrane-proximal $\mathrm{pH}$ in an in vitro membrane assay. Interestingly, bepridil and amiodarone recently have been shown to also block another $\mathrm{pH}$-sensitive membrane-proximal en-
A
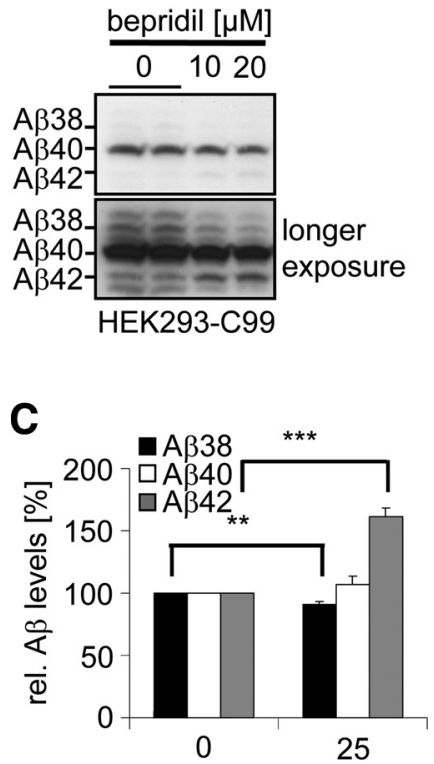

bepridil concentration $[\mu \mathrm{M}]$

E

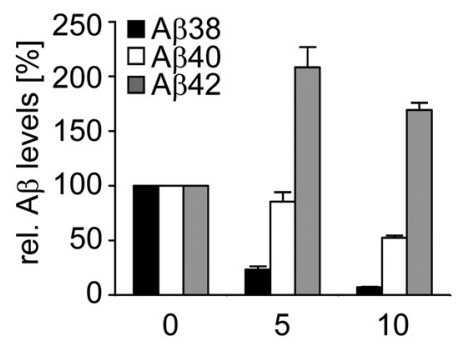

bepridil concentration $[\mu \mathrm{M}]$
B

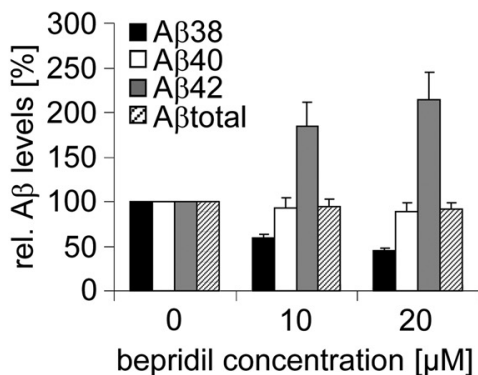

D

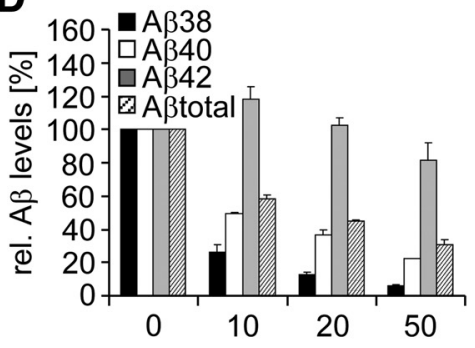

bepridil concentration $[\mu \mathrm{M}]$

$\mathbf{F}$

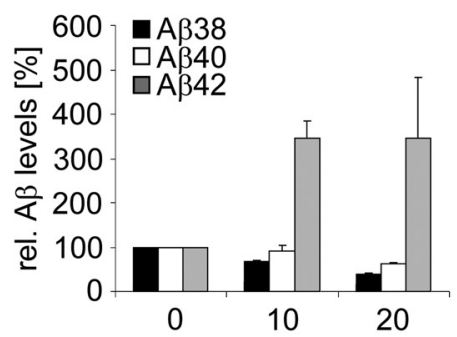

amiodarone concentration $[\mu \mathrm{M}]$

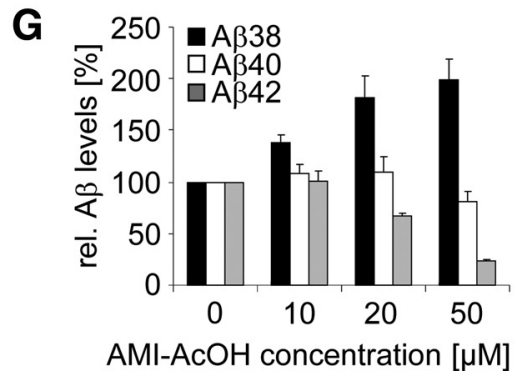

Figure 4. Bepridil and amiodarone modulate $\gamma$-secretase cleavage. $A$ and $B$, HEK293 cells expressing $C 99$ were treated for $16 \mathrm{~h}$ with the indicated concentrations of bepridil. $\boldsymbol{A}$, The different $A \beta$ species were analyzed on an $11 \%$ urea gel. $\boldsymbol{B}$, Quantification of the results from $\boldsymbol{A}$. Indicated are the mean and SD of two independent experiments. Bepridil acts as iGSM, decreasing $A \beta 38$ and increasing $A \beta 42$. $A \beta 40$ and total $A \beta$ were unaffected. $C$, iGSM effect of bepridil in an in vitro $\gamma$-secretase assay using purified, reconstituted $\gamma$-secretase and recombinant $C 99$ as a substrate. $A \beta$ species were determined by sandwich immunoassay $(n=4)$. $D$, HEK293-APPswe cells were treated as above with bepridil and $A \beta$ species were determined by sandwich immunoassay. The dual modulatory effect led to a strong decrease in $A \beta 38$ and $A \beta 40$ and only minor changes of $A \beta 42$. $E$, Primary neurons from $\operatorname{Tg} 2576$ mice were incubated as in $\boldsymbol{D}$ with bepridil, which resulted in a strong reduction of $A \beta 38$, a milder reduction of $A \beta 40$, and an increase of $A \beta 42 . \boldsymbol{F}$, HEK293 APP swe cells were treated with amiodarone as in $\boldsymbol{D}$. For amiodarone, the decrease in $A \beta 38$ and $A \beta 40$ is less pronounced compared with bepridil in $\boldsymbol{D}$ and $A \beta 42$ is further increased. G, HEK293-APPswe cells were treated as above with the amiodarone derivative AMI-ACOH. In contrast to amiodarone, $\mathrm{AMI}-\mathrm{AcOH}$ acts as a straight $\mathrm{GSM}$ increasing $\mathrm{A} \beta 38$ and decreasing $A \beta 42$. rel., Relative. ${ }^{* *} p<0.01 ;{ }^{* * *} p<0.001$, determined with unpaired, two-tailed $t$ test.

dosomal process - the insertion of anthrax toxin into endosomal membranes_-by raising the endosomal pH (Sanchez et al., 2007). We found that the inhibition of $\beta$-secretase cleavage both in cells and in guinea pigs occurred at concentrations of bepridil and amiodarone that are therapeutically achievable in the plasma of patients. 
Whether both compounds also block $\beta$-secretase cleavage in the brain remains to be tested. Bepridil and amiodarone are chronically tolerated in patients. This suggests that a mild rise in the endosomal pH may be a clinically acceptable strategy. In fact, a similar approach is used for the treatment of the bacterial infection chronic Q fever, where the antimalarial drug chloroquine and its derivatives are used to raise the lysosomal pH (Rolain et al., 2007).

Weak bases, such as bepridil and amiodarone, become concentrated in acidic organelles, where they are protonated and retained. This principle may also help in the development of active site-directed BACE1 inhibitors. One such compound was found to have a higher potency in cells when it contained an additional amino group (Yang et al., 2006). Although the reason for the amino group requirement is not fully understood, it is possible that the amino group targets the inhibitor to the endosome, resulting in higher local inhibitor concentrations at the site of $\beta$-secretase cleavage and a more efficient inhibition of $\beta$-secretase. Potentially, such inhibitors also raise the endosomal $\mathrm{pH}$ and thereby additionally inhibit $\beta$-secretase cleavage.

Another outcome of our study is that amiodarone and bepridil raised the membrane-proximal $\mathrm{pH}$ in the membrane assay, but did not affect the bulk $\mathrm{pH}$. This situation may also be found in endosomes in living cells. Direct experimental proof is difficult, because the available technology to determine the $\mathrm{pH}$ in the endolysosomal system in living cells, including the one used in this study, does not allow to distinguish between $\mathrm{pH}$ changes occurring in the bulk of the endosomal lumen versus those that are restricted to the membrane-proximal area. However, the compounds' chemical properties fit well with an effect primarily on the membrane-proximal $\mathrm{pH}$. By inserting into the membrane, amiodarone and bepridil repel protons from the membrane surface and thereby raise the membrane-proximal $\mathrm{pH}$. This puts $\mathrm{BACE} 1$ in an environment where the $\mathrm{pH}$ is no longer favorable for its activity. This localized area of action of bepridil and amiodarone may be helpful when the use of such compounds is considered for therapeutic purposes, as other processes in the endosomal and lysosomal lumen may occur normally. In fact, the processing of the soluble proenzyme procathepsin L, which takes place in the lumen of late endosomes, is not affected by amiodarone (Stadler et al., 2008).

Surprisingly, we found that amiodarone and bepridil—in addition to their inhibitory effect on $\beta$-secretase cleavage-additionally modulate $\gamma$-secretase in an inverse manner (iGSM). Together with their inhibitory effect on $\beta$-secretase cleavage, this resulted in a strong reduction of $\mathrm{A} \beta 38$, a prominent reduction of $\mathrm{A} \beta 40$, and only a minor reduction of $\mathrm{A} \beta 42$. The compounds' modulatory effect on $\gamma$-secretase seems to be independent of their alkalizing ability, because the effect also occurred in the cell-free $\gamma$-secretase assay. Moreover, the basic amino group was not required for the modulation of $\gamma$-secretase, since AMI$\mathrm{AcOH}$, which lacks the amino group, still modulated the cleavage specificity of $\gamma$-secretase. Additionally, other alkalizing compounds, such as ammonium chloride, which inhibit $\beta$-secretase cleavage, do not affect the cleavage specificity of $\gamma$-secretase (Vingtdeux et al., 2007). Furthermore, other compounds with GSM activity, such as fenofibrate and flurbiprofen, do not contain amino groups (Kukar et al., 2008). Thus, the dual modulators amiodarone and bepridil are likely to use two different parts of the molecule for the inhibition of $\beta$-secretase (amino group) and the modulation of $\gamma$-secretase (probably the hydrophobic core).

The first GSMs were identified in 2001 (Weggen et al., 2001). Proposed mechanisms of action include a direct binding to C99
(Kukar et al., 2008) and to the $\gamma$-secretase complex (Eriksen et al., 2003) and a change in the dimerization strength of C99 (Munter et al., 2007). GSMs are a chemically heterogeneous group of compounds. When comparing the structure of published GSMs, we found that sGSMs contain a free carboxylic acid group, which is absent in iGSMs. In line with this observation, we found that the addition of a carboxyl group to amiodarone (AMI-AcOH) was able to invert the specificity to $\gamma$-secretase. A similar result was observed in a recent study, which showed that a hydrophobic compound with iGSM activity could be converted to a sGSM by the addition of a free carboxylic acid group (Narlawar et al., 2007). Thus, the addition of a free acidic group may be a more generally applicable strategy to convert an iGSM to an sGSM.

Mechanistically, it is not yet clear why the carboxyl group is required for the sGSM effect. $\gamma$-Secretase seems to cleave first at the C-terminal end of the transmembrane domain of C99 and then proceed in a stepwise fashion toward the middle of the transmembrane domain, until the $\mathrm{A} \beta$ peptide is short enough to slip out of the membrane. A recent study suggested that the negatively charged free carboxylic acid of sGSMs binds and neutralizes the positively charged lysine 28, which forms the luminal, membrane-anchoring residue in the C99 sequence (Kukar et al., 2008). This neutralization may allow C99 to insert more deeply into the membrane. As a consequence, $\gamma$-secretase may proceed up to more $N$-terminally located residues, resulting in more $\mathrm{A} \beta 38$ and less $A \beta 42$. Such a mechanism is in agreement with previous findings by us and others, which showed that a change in the length of the C99 transmembrane domain has a profound effect on the cleavage specificity of $\gamma$-secretase (Murphy et al., 1999; Lichtenthaler et al., 2002). Based on our results, we conclude that the hydrophobic core of amiodarone and bepridil is sufficient for modulation of $\gamma$-secretase and that the presence or absence of a free carboxylic group — or potentially another acidic group_-determines the sGSM or iGSM activity, respectively.

Together, our work serves as a proof-of-principle showing that it is possible to identify dual modulators, which simultaneously target $\beta$ - and $\gamma$-secretase cleavage of APP. This indicates that drugs developed against one of the two enzymes should always be inspected for potential additional effects on the other protease cleavage. Because the dual modulatory effect of amiodarone and bepridil occurs at concentrations that are therapeutically reached in the plasma of patients, both compounds may be used for future drug development. We envisage the generation of four different classes of compounds. First, modification of the hydrophobic core may yield drugs that lack GSM activity and selectively inhibit $\beta$-secretase cleavage. Second, AMI-AcOH provides a new structural scaffold for sGSMs, which do not affect $\beta$-secretase. The development of new sGSMs is needed because a previously identified sGSM failed in a recent phase III clinical trial for lack of efficacy (Rafii and Aisen, 2009). Third, dual modulators may be generated that simultaneously inhibit $\beta$-secretase cleavage and act as sGSMs on $\gamma$-secretase. An ideal dual modulator should comprise of the following three structural elements: (1) a hydrophobic core with aromatic rings for membranetargeting, (2) an acidic group to allow for sGSM activity, and (3) an amino group and a net positive charge to guarantee the inhibitory effect on $\beta$-secretase by raising the membrane-proximal endosomal pH. Such compounds would allow the lowering of total $\mathrm{A} \beta$ levels and the additional specific lowering of $\mathrm{A} \beta 42$, which should result in an enhanced total reduction of $\mathrm{A} \beta 42$ levels. Fourth, given the accumulation of weak bases in acidic organelles, we consider that the addition of an amino group may be used as a more general strategy for endosomal and 
lysosomal targeting of hydrophobic compounds, which may be developed against other membrane protein targets in both acidic compartments.

\section{References}

Berjukow S, Döring F, Froschmayr M, Grabner M, Glossmann H, Hering S (1996) Endogenous calcium channels in human embryonic kidney (HEK293) cells. Br J Pharmacol 118:748-754.

Capell A, Meyn L, Fluhrer R, Teplow DB, Walter J, Haass C (2002) Apical sorting of beta-secretase limits amyloid beta-peptide production. J Biol Chem 277:5637-5643.

Cole SL, Vassar R (2008) BACE1 structure and function in health and Alzheimer's disease. Curr Alzheimer Res 5:100-120.

Di A, Brown ME, Deriy LV, Li C, Szeto FL, Chen Y, Huang P, Tong J, Naren AP, Bindokas V, Palfrey HC, Nelson DJ (2006) CFTR regulates phagosome acidification in macrophages and alters bactericidal activity. Nat Cell Biol 8:933-944.

Dovey HF, John V, Anderson JP, Chen LZ, de Saint Andrieu P, Fang LY, Freedman SB, Folmer B, Goldbach E, Holsztynska EJ, Hu KL, JohnsonWood KL, Kennedy SL, Kholodenko D, Knops JE, Latimer LH, Lee M, Liao Z, Lieberburg IM, Motter RN, et al. (2001) Functional gammasecretase inhibitors reduce beta-amyloid peptide levels in brain. J Neurochem 76:173-181.

Eriksen JL, Sagi SA, Smith TE, Weggen S, Das P, McLendon DC, Ozols VV, Jessing KW, Zavitz KH, Koo EH, Golde TE (2003) NSAIDs and enantiomers of flurbiprofen target gamma-secretase and lower Abeta 42 in vivo. J Clin Invest 112:440-449.

Facchinetti F, Fasolato C, Del Giudice E, Burgo A, Furegato S, Fusco M, Basso E, Seraglia R, D’Arrigo A, Leon A (2006) Nimodipine selectively stimulates beta-amyloid 1-42 secretion by a mechanism independent of calcium influx blockage. Neurobiol Aging 27:218-227.

Freedman MD, Somberg JC (1991) Pharmacology and pharmacokinetics of amiodarone. J Clin Pharmacol 31:1061-1069.

Ghosh AK, Gemma S, Tang J (2008) Beta-secretase as a therapeutic target for Alzheimer's disease. Neurotherapeutics 5:399-408.

Grynkiewicz G, Poenie M, Tsien RY (1985) A new generation of Ca2+ indicators with greatly improved fluorescence properties. J Biol Chem 260:3440-3450.

Haass C, Hung AY, Schlossmacher MG, Teplow DB, Selkoe DJ (1993) Betaamyloid peptide and a 3-kDa fragment are derived by distinct cellular mechanisms. J Biol Chem 268:3021-3024.

Haass C, Capell A, Citron M, Teplow DB, Selkoe DJ (1995) The vacuolar $\mathrm{H}(+)$-ATPase inhibitor bafilomycin Al differentially affects proteolytic processing of mutant and wild-type beta-amyloid precursor protein. J Biol Chem 270:6186-6192.

Hamid R, Kilger E, Willem M, Vassallo N, Kostka M, Bornhövd C, Reichert AS, Kretzschmar HA, Haass C, Herms J (2007) Amyloid precursor protein intracellular domain modulates cellular calcium homeostasis and ATP content. J Neurochem 102:1264-1275.

Hardy J, Selkoe DJ (2002) The amyloid hypothesis of Alzheimer's disease: progress and problems on the road to therapeutics. Science 297:353-356.

Hartlage-Rübsamen M, Zeitschel U, Apelt J, Gärtner U, Franke H, Stahl T, Günther A, Schliebs R, Penkowa M, Bigl V, Rossner S (2003) Astrocytic expression of the Alzheimer's disease beta-secretase (BACE1) is stimulusdependent. Glia 41:169-179.

Hollingshead LM, Faulds D, Fitton A (1992) Bepridil: a review of its pharmacological properties and therapeutic use in stable angina pectoris. Drugs 44:835-857.

Hsiao K, Chapman P, Nilsen S, Eckman C, Harigaya Y, Younkin S, Yang F, Cole G (1996) Correlative memory deficits, Abeta elevation, and amyloid plaques in transgenic mice. Science 274:99-102.

Kamp F, Beyer K (2006) Binding of alpha-synuclein affects the lipid packing in bilayers of small vesicles. J Biol Chem 281:9251-9259.

Kuhn PH, Marjaux E, Imhof A, De Strooper B, Haass C, Lichtenthaler SF (2007) Regulated intramembrane proteolysis of the interleukin-1 receptor II by alpha-, beta-, and gamma-secretase. J Biol Chem 282: 11982-11995.

Kukar T, Murphy MP, Eriksen JL, Sagi SA, Weggen S, Smith TE, Ladd T, Khan MA, Kache R, Beard J, Dodson M, Merit S, Ozols VV, Anastasiadis PZ, Das P, Fauq A, Koo EH, Golde TE (2005) Diverse compounds mimic Alzheimer disease-causing mutations by augmenting Abeta42 production. Nat Med 11:545-550.
Kukar TL, Ladd TB, Bann MA, Fraering PC, Narlawar R, Maharvi GM, Healy B, Chapman R, Welzel AT, Price RW, Moore B, Rangachari V, Cusack B, Eriksen J, Jansen-West K, Verbeeck C, Yager D, Eckman C, Ye W, Sagi S, et al. (2008) Substrate-targeting gamma-secretase modulators. Nature 453:925-929.

Lanz TA, Himes CS, Pallante G, Adams L, Yamazaki S, Amore B, Merchant KM (2003) The gamma-secretase inhibitor $N$-[N-(3,5-difluorophenacetyl)-Lalanyl]-S-phenylglycine t-butyl ester reduces Abeta levels in vivo in plasma and cerebrospinal fluid in young (plaque-free) and aged (plaque-bearing) Tg2576 mice. J Pharmacol Exp Ther 305:864-871.

Lichtenthaler SF, Beher D, Grimm HS, Wang R, Shearman MS, Masters CL, Beyreuther K (2002) The intramembrane cleavage site of the amyloid precursor protein depends on the length of its transmembrane domain. Proc Natl Acad Sci U S A 99:1365-1370.

Meredith JE Jr, Thompson LA, Toyn JH, Marcin L, Barten DM, Marcinkeviciene J, Kopcho L, Kim Y, Lin A, Guss V, Burton C, Iben L, Polson C, Cantone J, Ford M, Drexler D, Fiedler T, Lentz KA, Grace JE Jr, Kolb J, et al. (2008) P-glycoprotein efflux and other factors limit brain amyloid beta reduction by beta-site amyloid precursor protein-cleaving enzyme 1 inhibitors in mice. J Pharmacol Exp Ther 326:502-513.

Munter LM, Voigt P, Harmeier A, Kaden D, Gottschalk KE, Weise C, Pipkorn R, Schaefer M, Langosch D, Multhaup G (2007) GxxxG motifs within the amyloid precursor protein transmembrane sequence are critical for the etiology of Abeta42. EMBO J 26:1702-1712.

Murphy MP, Hickman LJ, Eckman CB, Uljon SN, Wang R, Golde TE (1999) Gamma-secretase, evidence for multiple proteolytic activities and influence of membrane positioning of substrate on generation of amyloid beta peptides of varying length. J Biol Chem 274:11914-11923.

Narlawar R, Baumann K, Czech C, Schmidt B (2007) Conversion of the LXR-agonist TO-901317-from inverse to normal modulation of gamma-secretase by addition of a carboxylic acid and a lipophilic anchor. Bioorg Med Chem Lett 17:5428-5431.

Page RM, Baumann K, Tomioka M, Pérez-Revuelta BI, Fukumori A, Jacobsen H, Flohr A, Luebbers T, Ozmen L, Steiner H, Haass C (2008) Generation of Abeta38 and Abeta42 is independently and differentially affected by familial Alzheimer disease-associated presenilin mutations and gammasecretase modulation. J Biol Chem 283:677-683.

Rafii MS, Aisen PS (2009) Recent developments in Alzheimer's disease therapeutics. BMC Med 7:7.

Rajendran L, Schneider A, Schlechtingen G, Weidlich S, Ries J, Braxmeier T, Schwille P, Schulz JB, Schroeder C, Simons M, Jennings G, Knölker HJ, Simons K (2008) Efficient inhibition of the Alzheimer's disease betasecretase by membrane targeting. Science 320:520-523.

Reimers S, Hartlage-Rübsamen M, Brückner G, Rossner S (2007) Formation of perineuronal nets in organotypic mouse brain slice cultures is independent of neuronal glutamatergic activity. Eur J Neurosci 25:2640-2648.

Rolain JM, Colson P, Raoult D (2007) Recycling of chloroquine and its hydroxyl analogue to face bacterial, fungal and viral infections in the 21st century. Int J Antimicrob Agents 30:297-308.

Rossner S, Sastre M, Bourne K, Lichtenthaler SF (2006) Transcriptional and translational regulation of BACE1 expression-implications for Alzheimer's disease. Prog Neurobiol 79:95-111.

Sanchez AM, Thomas D, Gillespie EJ, Damoiseaux R, Rogers J, Saxe JP, Huang J, Manchester M, Bradley KA (2007) Amiodarone and bepridil inhibit anthrax toxin entry into host cells. Antimicrob Agents Chemother 51:2403-2411.

Schägger H, von Jagow G (1987) Tricine-sodium dodecyl sulfate-polyacrylamide gel electrophoresis for the separation of proteins in the range from 1 to 100 kDa. Anal Biochem 166:368-379.

Schöbel S, Neumann S, Hertweck M, Dislich B, Kuhn PH, Kremmer E, Seed B, Baumeister R, Haass C, Lichtenthaler SF (2008) A novel sorting nexin modulates endocytic trafficking and alpha-secretase cleavage of the amyloid precursor protein. J Biol Chem 283:14257-14268.

Schrader-Fischer G, Paganetti PA (1996) Effect of alkalizing agents on the processing of the beta-amyloid precursor protein. Brain Res 716:91-100.

Shimizu H, Tosaki A, Kaneko K, Hisano T, Sakurai T, Nukina N (2008) Crystal structure of an active form of BACE1, an enzyme responsible for amyloid beta protein production. Mol Cell Biol 28:3663-3671.

Shiotani M, Harada T, Abe J, Sawada Y, Hashimoto K, Hamada Y, Horii I (2005) Practical application of guinea pig telemetry system for QT evaluation. J Toxicol Sci 30:239-247. 
Simard JR, Kamp F, Hamilton JA (2008) Measuring the adsorption of fatty acids to phospholipid vesicles by multiple fluorescence probes. Biophys J 94:4493-4503.

Stadler K, Ha HR, Ciminale V, Spirli C, Saletti G, Schiavon M, Bruttomesso D, Bigler L, Follath F, Pettenazzo A, Baritussio A (2008) Amiodarone alters late endosomes and inhibits SARS coronavirus infection at a postendosomal level. Am J Respir Cell Mol Biol 39:142-149.

Steiner H, Fluhrer R, Haass C (2008) Intramembrane proteolysis by gamma-secretase. J Biol Chem 283:29627-29631.

Teissié J, Prats M, Soucaille P, Tocanne JF (1985) Evidence for conduction of protons along the interface between water and a polar lipid monolayer. Proc Natl Acad Sci U S A 82:3217-3221.

Vingtdeux V, Hamdane M, Bégard S, Loyens A, Delacourte A, Beauvillain JC, Buée L, Marambaud P, Sergeant N (2007) Intracellular pH regulates amyloid precursor protein intracellular domain accumulation. Neurobiol Dis 25:686-696.

Weggen S, Eriksen JL, Das P, Sagi SA, Wang R, Pietrzik CU, Findlay KA,
Smith TE, Murphy MP, Bulter T, Kang DE, Marquez-Sterling N, Golde TE, Koo EH (2001) A subset of NSAIDs lower amyloidogenic Abeta42 independently of cyclooxygenase activity. Nature 414: 212-216.

Wiltfang J, Smirnov A, Schnierstein B, Kelemen G, Matthies U, Klafki HW, Staufenbiel M, Hüther G, Rüther E, Kornhuber J (1997) Improved electrophoretic separation and immunoblotting of beta-amyloid (A beta) peptides 1-40, 1-42, and 1-43. Electrophoresis 18:527-532.

Winkler E, Hobson S, Fukumori A, Dümpelfeld B, Luebbers T, Baumann K, Haass C, Hopf C, Steiner H (2009) Purification, pharmacological modulation, and biochemical characterization of interactors of endogenous human gamma-secretase. Biochemistry 48:1183-1197.

Yang W, Lu W, Lu Y, Zhong M, Sun J, Thomas AE, Wilkinson JM, Fucini RV, Lam M, Randal M, Shi XP, Jacobs JW, McDowell RS, Gordon EM, Ballinger MD (2006) Aminoethylenes: a tetrahedral intermediate isostere yielding potent inhibitors of the aspartyl protease BACE-1. J Med Chem 49:839-842. 